\title{
ONLINE EDUCATION IN MALAYSIA: THE GOOD, THE BAD, THE UGLY AND THE WAY FORWARD
}

\author{
Muzaffar Syah Mallow ${ }^{1}$ and Syed Saddiq Syed Abdul Rahman ${ }^{2}$ \\ ${ }^{1}$ Senior Lecturer, Faculty of Syariah \& Law, Universiti Sains Islam Malaysia (USIM), Bandar Baru \\ Nilai, Negeri Sembilan Darul Khusus, Malaysia, \\ ${ }^{2}$ Member of Parliament, Muar, G-6, No. 1, Eco Avenue, Jalan Abdul Rahman, Muar, Johor Darul \\ Ta'zim, Malaysia
}

\begin{abstract}
With the spread of the contagious Novel Coronavirus (Covid-19) in early 2020, online education has become a very hot topic of discussion not only in Malaysia but whole over the world. Unlike other types of known viruses, Covid-19 is a completely new type of virus which can cause serious health concern to those who have been infected with it especially to the high risk group of peoples. Up to December 2020, millions of peoples have been infected with such virus and over a million peoples have died due to it which being reported all over the world. Because of the bad effects of Covid-19 to people health and safety, governments around the world have taken drastic steps to stop the spread of the virus and such step includes by implemented a partial or total lockdown of the whole country. Malaysia also has taken such drastic step in middle of March 2020 through the enforcement of the Movement Control Order (MCO) which witnessed the closure of nearly all working sectors and entire educational sectors in the country. Due to the MCO, all schools and universities in the country have been closed. MCO has been enforced in the country for nearly two months beginning in the middle of March until early May 2020. Though schools and universities have been closed, the Malaysian government has encourage all parties in this sector namely the educators and students to make use of online teaching and learning process to continue with their lesson. It is not easy for both the educators and students both in schools and universities to adapt themselves with this new norm of teaching and learning process as online teaching and learning has not fully been used by them previously. Almost all educators and students in the country still adopt the traditional method of teaching and learning process namely through face to face interaction in classroom and lecture hall. Thus it is the object of this research paper to analyse this issue further by briefly examine the concept of online education itself, analysing in general the pros and cons it carry and identifying the future of online education particularly in Malaysia.
\end{abstract}

Keywords: Online, education, Malaysia

\subsection{INTRODUCTION}

The coming of new decade should have been fill in with many joys and hopes for a better future. Nobody in the world could imagine that their life could have drastically change in 2020 due to the spread of Novel Coronavirus (Covid-19). The spread of Covid-19 all over the world has caused many problems to people life 
socially and economically. Up to early December 2020, more than 68 million peoples have been reported infected with such virus in 191 countries/territories. More than 1.5 million peoples have died due to the infection from such disease all over the world. (The Johns Hopkins Coronavirus Resource Center (CRC), 2020). In Malaysia, more than 76,000 of Covid-19 infection cases with more than 390 deaths been reported at the same period. (Ministry of Health, Malaysia, 2020). Due to the rapid spread of Covid-19, the leading world health body namely the World Health Organization (WHO) declared Covid-19 as a global pandemic. (Free Malaysia Today, 2020). A pandemic is an epidemic of an infectious disease that has spread across a large region affecting the life and well-being of a substantial number of people. (Jacqueline Howard, 2020). Throughout the recorded human history, a number of deadly and serious pandemics of diseases have been recorded like smallpox and tuberculosis. The most well-known and fatal pandemics which been recorded in human history includes the Black Death which killed an estimated 75 to 200 million people in the $14^{\mathrm{TH}}$ century (ABC/Reuters, 2008 and BBC, 2001.), the 1918 influenza pandemic (Spanish flu) which killed 17 million and 50 million (Centers for Disease Control and Prevention, 2020), Human immunodeficiency virus infection and acquired immunodeficiency syndrome or HIV/AIDS which had caused an estimated 32 million deaths worldwide until today (UNAIDS, 2020) and the current Covid-19. Covid-19 is a contagious virus caused by severe acute respiratory syndrome coronavirus 2 (SARS-CoV-2). Though people who have been infected with Covid-19 having mild symptoms, such virus can also cause serious health concern to certain groups of peoples like the elderly and people who have certain underlying medical conditions. The first case of Covid-19 infection was identified in Wuhan, China, in December 2019. It has since spread worldwide, leading to an ongoing pandemic. (Centers for Disease Control and Prevention, 2020).

Due to the health risk and contagious nature of Covid-19, government around the world has to take drastic preventive measures to stop the spread of Covid-19. Among the drastic preventive measures taken by many governments includes by forcing people to wear face mask, enforcing social distancing and implementing a partial and total lockdown of the entire country. There are even curfews, quarantine, and similar restrictions which been taken by governments in order to control the spread of such disease. By April 2020, about half of the world's population was under some kind of lockdown, with more than 3.9 billion people in more than 90 countries or territories having been asked or ordered to stay at home by their respective governments. (Alasdair Sandford, 2020). All these drastic preventive measures need to be taken in order to control the number of infection rate within their country. Besides the drastic preventive measures imposed by respective governments, the WHO also has issued their own preventive measures to the public in order to reduce the chances of Covid-19 infection. Among the preventive measures which has been given to the public includes by asking the public to stay at home, avoiding crowded places, ventilating in door spaces, constantly washing hands with soap and water, practicing good respiratory hygiene, and avoiding touching the eyes, nose, or mouth with unwashed hands. (World Health Organization, 2020). Malaysian government too has taken similar drastic measures and took advices from the WHO in order to protect people in the country from Covid-19 infection. On March 18, 2020, the Malaysian Prime Minister, Tan Sri Muhyiddin Yassin had made a broadcast nationwide speech and officially declared the "Movement Control Order" (MCO) (In Malaysia: Perintah Kawalan Pergerakan or PKP) which been seen by many as a partial lockdown of the entire country in order to curb the spread of Covid-19. (Tashny Sukumaran, 2020). This partial lockdown order need to be taken due to the sharp rise of in the number of infection of Covid-19 in the country. This can be understand clearly from the special message delivered by the Prime Minister himself two days before the enforcement of the MCO order. Through the special message, the Prime Minister stated that:
"In Malaysia, there was a sharp rise in the number of cases: 190 cases recorded yesterday and an additional 125 cases today. The total number of cases now stand at 553 cases. From that number, 511 are being treated, whereas 42 have fully recovered. The Government takes this current trend very seriously, especially the rise of the second wave of new infections. Our priority now is to prevent the further spread of this virus within the population. The current scenario requires drastic measures to be taken to resolve the situation as soon as possible. To that end, the Government has decided to implement a nationwide Restriction of Movement Order beginning 18th of March until 31st of March". (The Prime Minister Special Message on Covid-19 - 16 March 2020).

The MCO orders was enforced through the country Prevention and Control of Infectious Diseases Act 1988 [Act 342] and the Police Act 1967 [Act 344] in order to give legal teeth to its implementation and to imposed penalty any people who breaks such MCO order. The MCO order has included the following restrictions: General prohibition of mass movements and gatherings across the country including religious, sports, social and cultural activities. To enforce this prohibition, all houses of worship and business premises would be closed, except for supermarkets, public markets, grocery stores and convenience stores selling everyday 
necessities. Specifically for Muslims, the adjournment of all religious activities in mosques including Friday prayers would be in line with the decision made on 15 March 2020 by the Special Muzakarah Meeting of the National Council for Islamic Affairs. Sanctions covering all Malaysians travelling abroad. For those who have just returned from overseas, they would be required to undergo a health check and a 14-day quarantine (or self-quarantine). Restrictions on the entry of all tourists and foreign visitors into the country. Closure of all kindergartens, government and private schools including daily schools, boarding schools, international schools, tahfiz centres and another primary, secondary and pre-university institutions. Closure of all public and private higher education institutions (IPTs) and skills training institutes nationwide. Closure of all government and private premises except those involved in essential services (water, electricity, energy, telecommunications, postal, transportation, irrigation, oil, gas, fuel, lubricants, broadcasting, finance, banking, health, pharmacy, fire, prison, port, airport, safety, defence, cleaning, retail and food supply. (New Straits Times, March 16, 2020). On 25 March, the Prime Minister through a live national broadcast announced a first extension of the MCO order to last until April, 14. (Kenneth Tee, March 25, 2020). On 10 April, the Prime Minister announced a second extension of the MCO by another fortnight until 28 April. (Bernama, 2020). On the night of April 23, the Prime Minister announced a third extension of the MCO by two weeks till May 12. (Bernama, 2020). As the number of Covid-19 infection has gone down, on May 1 , during Labour Day speech, the Prime Minister has replaced the MCO order with the Conditional Movement Control Order (CMCO or Conditional $\mathrm{MCO}$ ), a relaxation of regulations regarding the $\mathrm{MCO}$, with its main goal was to reopen the national economy in a controlled manner. (Bernama, 2020). Satisfying with the current Covid-19 situation the country, on June 7, the Prime Minister announced that the CMCO would end on June 9, with the country entering into the Recovery Movement Control Order (RMCO) phase between June, 10 and August, 31. (Cindi Loo, 2020). On August 28, the Prime Minister announced the extension of the RMCO by a further 4 months until December 31, 2020. (Amir Yusof, 2020).

Because of the MCO order, all schools and universities in the country have been closed for several months. As a result of this closure order, students both in schools and universities are required to stay in their house for their own safety and protection from being infected with Covid-19. There are many university students who are unable to go back to their hometown due to the time limitation between the MCO order announcement made by the Prime Minister and its enforcement date. As a result of this, there are many university students have been stranded inside their campus dormitory and rental house. This is unavoidable as to country need to take measures to curb the spread of Covid-19. (Khairah N. Karim, 2020). Universities management have been asked by the government to protect the well-being and welfare of all the students who have been stranded in the campus and their rental house throughout the MCO order period. Even since MCO order been implemented, it has disturb the teaching and learning process of the students both at school level as well as at university level. The disturbance towards teaching and learning process not only happen in Malaysia, but also all over the world. (Simon Burgess, Hans Henrik Sievertsen, 2020). Fear over the further disturbance towards students educational process, the government has encourage all educational sectors in the country to utilized any available technologies to conduct the teaching and learning process through online basis. (Radzi Razak, 2020). This give rise to the issue of online education. Ever since the Covid-19 pandemic started, online education has become a very hot topic of discussion among the people. Online education being seen by many especially by parents as the ultimate way to protect the pupils from infection of Covid-19 and prevent the further spread of such disease in the community. (Eleanor Busby, 2020 and Soo Wern Jun, 2020).

What is online education? Online education is electronically supported learning that rely on the use of Internet for teacher/lecturer and student interaction and the distribution of class/lecture materials. Online education is a form of education where teachers/lecturers and students use their home computers through the internet to communicate and implement the teaching and learning process without having the need for them to be present face to face at classroom or lecture hall. Online education has make education more accessible than ever before. Online education goes by many names like e-learning (electronic learning), $\mathrm{m}$ learning (mobile learning), computer-aided distance education and others. Online education or also known as e-learning process is not something new in the country. Before the start of the Covid-19 pandemic, such modern method of teaching and learning has been implemented by many universities and schools in the country. (General references can be made to Siti Hajar Halili, Shukri Sulaiman, and Mohd Razha Abd Rashid, 2011, pp. 55 - 65 and Farah Nurshahira Zulkifli and Md Yusoff Daud, 2017, pp. 99 - 106). The using of online teaching and learning process has been encourage by the government ever since internet been used in the country. With the creation of many online platforms like Zoom, Google Meet dan Webex, it has attracted youngster particularly the millennial generation towards online teaching and learning process. (General references can be made to Siti Hajar Taib, Mohd Azaharin Ismail, and Maimun Aqsha Lubis Abdin Lubis, 2019, pp: 38 - 54). In 2020, due to the spread of Covid-19, many schools and universities all over the 
world including in Malaysia enrolling in online courses. (Hye Jung Han, 2020). Though online teaching and process has been around for many years, many countries including Malaysia seem facing with many challenges and struggles to ensure the smoothness and effectiveness of such modern method of teaching and learning. There is no doubt, every method of teaching and learning has its own strength and weaknesses which will be further generally analyze and to be discussed separately below.

\subsection{THE GOOD SIDES OF ONLINE EDUCATION}

Covid-19 pandemic has certainly marked a dark history in the timeline of mankind. Even though countries around the world have taken necessary actions and steps in preventing the spread of the outbreak, humankind is severely affected. The global economy is showing signs of slowing down. Various industries are trying to stay afloat in an environment where a lot of businesses are going down the drain, as well as people are trying their best to survive the impact of the outbreak. (Priya, 2020). Apart from the economy, the education sector has been greatly confronted with the on-going outbreak. Schools, nurseries, vocational centres, polytechnics, community colleges, and universities around the world are forced to close down in order to curb Covid-19 disease from spreading wildly. A report by the Committee for the Coordination of Statistical Activities (CSSA) (2020) has shown that 1.6 billion learners were affected with the closure of educational institutions, and that is approximately $90 \%$ of the global student population. (Ritesh Presswala, 2020). The question that needs to be answered now is, how will education continue in the face of a pandemic? What are the necessary mechanisms needed to be structured so that the global student can acquire knowledge smoothly?

Pushing through in such difficult circumstances, a lot of education institutions adopted a distance method of learning, and in a world where technology is progressing at a rapid pace, the online method is considered one of the most effective way to continue the process of teaching and learning. This method corresponds with the new norm that mankind needs to adjust with a norm where individuality and their safety is highly prioritized. Maintaining a safe distance, constantly being clean, minimizing interaction with other individuals is the only way to break the chain and by following such rules, the process of acquiring knowledge can continue and to guarantee their safety, it is to be done within the confined walls of their homes. Furthermore, online teaching and learning are not foreign in the pedagogy; in fact, it has been one of the methods that the academic world has espoused in recent years. Renowned institution of higher education such as New York University has started their own version of a virtual university, called NYU Online (Kentnor, 2015). The launch of such establishment was a response to the increasing demand in transforming the academia from the traditional classroom setting to the online realm. There are many good sides or benefits in adopting and implementing online education. (Sander Tamm, 2019). In general, online education provide more flexible learning schedules, where it can offers teaching and learning process from anywhere and at any time which suit both educators and students. Online education can cut financial expenses for the students. Online courses fees are often cheaper and students can save their money from having the need to travel from their house or hostel to the classroom and spending money to buying school or campus meals. Online education teaches both educators and students to be more disciplined and responsible towards their teaching and learning duties and responsibilities. Online education can provide security and safety for the students as students will no need to travels a lot from their house or hostel to the classroom. Less travelling activities mean less exposure to theft, robbery, and other potential criminal violence's. Online education can protect educator and students health from any contagious diseases like Covid-19 which being faced by us now. Through online education, students can reviews lectures notes more clearly, instantly and effectively as everything will appear in front of their computer screen. Online education can developed more confidence level among students. Some students don't feel confident enough to speak out during face to face meeting in the classroom. However, students are able to speak out through online process. In an online environment, students can spend as much time as they want thinking about and honing their own ideas. This can lead to greater confidence and develop more interesting and fruitful discussions. Online education can eliminate physical judgments that can cloud rational discussion among students and educators. In the long term, online education can also save the environment. Less paper will be used thus can save the use of paper and prevent paper waste. Online education can also teach students computer skills which are vital for their survival in the modern world which demand high tech skills from workers.

Furthermore, the exploration of the method of online learning and teaching is also pushing the frontiers of education itself, especially in making education accessible to everyone. There are various discussions on the status of education. In retrospect, education has always been seen as a privilege to which only people of certain background could acquire. Yaseen (2019) argued that in modern-day Pakistan, a significant number of children between the ages of five to 16 are out of school. 25.2 million Children are still struggling with having access to education even though it is within their constitutional right. Viewing this is a global issue, 
countries around the world are working hard in mitigating it and trying their best to make education accessible. Countries such as Norway and Germany believe that education is important and there is consensus from their citizens themselves that education in that sense should be free, especially in tertiary level (Kohli, 2015). With more people having access to tertiary education, there is a guarantee in producing proactive and educated citizens. Besides that, Samuels (2011) discussed that the prevalent dialogue when it comes to providing free education would be producing a more educated workforce, but a more important outcome of it would be generating an educated community. However, achieving such a goal would mean that there are huge hurdles that needed to be overcome. Providing free education may sound like a simple task, but it takes a lengthy process that may take up to more than just policy reformations. With online learning and teaching becoming more prevalent, education institutions are a step closer in realizing such an idea. With budget cuts and revisions on institutional spending, education establishments now have more power in strategizing in increasing the enrollment rate as well making education more appealing to the general masses. Dworak (2020) discussed that the current pandemic is causing a different form of a recession that the world has ever seen. This form of recession is not the kind that leaves room for people to take their time off work and continue studying, but it is the kind that leaves people in limbo. Education institutions are now in a place to manoeuvre a budget that can accommodate the online learning climate especially at a time where college enrollment is at a declining rate. Through such means, they will be able to allocate more funding on research, grants, projects, scholarships, and many other important spendings to attract more people to enroll in university, as suggested by Friga (2020). Ott (2020) reported that even though many educational institutions are struggling with their students' enrollment, for-profit colleges have seen a rise in their admission rates as they have cleverly managed their budgeting and catered to the distance learning environment. The increase in their admission rate shows how affordable education in times of crisis makes tertiary education accessible and appealing to the general masses. Furthermore, through such method also, more people have access to tertiary education, to which previously it is only accommodating to people who can commit to a régime of a full-time student. A lot of individuals do not have the luxury of being a full-time student due to financial and time constraint. The full-time student lifestyle is quite extensive to which only a certain group of individuals can commit to it. It is now common for university goers to juggle study and work part-time concurrently. University students take up part-time jobs for several reasons, amongst them to which Hall (2010) opined, "This growth in part-time employment has been attributed to the increasing financial burden being imposed on students as a result of increased university fees and a reduction in the number and value of scholarships and other forms of student support". With online learning in place, it eases the burden on such matters. Not only universities budgeting can now be revised, but learning is also something that can be done in the comfort of the student's home. Conclusively, the method of online learning and teaching, coupled with affordable rate opens education opportunity for more people, especially during trying times like the one we are facing now due to the spread of the pandemic.

The core of teaching and learning has also always been defined through the dynamic engagement between students and teachers. Over the years, we have seen such engagement evolve in accommodating to the rapid technological progress that the world is going through. However, the traditional classroom setting has always been the preferred choice by instructors when it comes to spreading knowledge. As discussed by Kemp and Grieve (2014), there is an important element that makes face-to-face classes unique, and it cannot be easily replicated through virtual classes, and that element is the element of community engagement. Such engagement nurtures a strong sense of togetherness between students, simultaneously it also motivates them to do well in their study. Even with such benefits, education institutions around the world are pressured to assimilate virtual methods in their teaching and learning as a response to the demand of present technological advancement in education. With the Covid-19 pandemic not going away anytime soon, instructors around the world are left with no options but to fully commit to the methods of online teaching and learning.

The situation that education instructors are placed in now is quite tough. The online learning and teaching climate have pushed them to explore the various approaches of the teaching pedagogy. Teaching in such an environment may not sound like a challenge. The general masses are always presented with a simplistic view of online classes such as attending online conference calls. However, online teaching and learning are extremely different, and it can be exceptionally stressful for students and instructors, not to mention that the transition from the conventional class to the online class setting was very much immediate. Local reporter, Ida Lim reported that the transition from face to face classroom to the online learning classroom has stressed out a huge number of students, and the situation is made worse with connectivity issues, workload stress, unconducive home environment, and online learning anxiety. (Ida Lim, 2020). Therefore, to allay arising issues concerning online learning and teaching, there have been calls in finding and exploring new and 
effective ways of learning and teaching. Instructors now are challenged to explore the various platforms in making teaching and learning interactive and appealing to students, especially when dealing with students ranging from kindergarten level, all the way to high school level. With major examinations being cancelled, teachers are moving past intensive examination-based exercises and exploring more options. With online learning and teaching becoming more popular in the wake of the pandemic, so are online learning platforms. Coursera, Udemy, and Khan Academy are not foreign to the online education sector, however, Minecraft Education Edition and Roblox Education Edition are presenting an interactive method of learning and teaching and it is famously used during online learning and teaching sessions. Rogers (2020) stated:

\begin{abstract}
"Though it was used in schools long before anyone heard of COVID-19, its popularity has exploded in the virus' wake, with a whopping 63 million pieces of content having been downloaded from the Minecraft: Education Collection marketplace since March. Since its release in 2011, Minecraft has amassed an incredible 126 million active players around the world, a number that undoubtedly continues to grow as the fall school season ramps up".
\end{abstract}

Besides, interactive platforms such as these keep the students engaged in their lesson and help in retaining their interest. Other platforms such as Quizizz are also now employed in class as its structure and assessment templates are compatible with difficult subjects. Permana and Permawati (2019) reported that the platform helps students in learning a difficult language such as German through a smooth process as the platform built-in imitates real-life language learning instructions and its interactive nature has helped the students accustomed themselves with online learning platforms. Clearly, the rise of online teaching and learning has changed the way of teaching and the utilization of interactive online learning platform has helped in retaining students' interest in learning.

\title{
3.0 THE BAD AND UGLY SIDES OF ONLINE EDUCATION
}

Besides highlighting the good sides of online education above, we also should know that online education also has its own problems or the bad sides. Among the most common problems or bad sides in making online education a success in the country is lack of facilities to carry out online education and poor online skills among the educator and student themselves. (General reference can be made to Ida Lim, 2020 and Justin Ong, 2020). Besides that, there are other identifiable reasons which can make online education less attractable to people (Sander Tamm, 2019): 1. Student's feedback is rather limited. It can be very tough process for the educators to give immediate feedback to the students by using online teaching and learning process. The process of giving immediate feedback might be more difficult for school students compared to universities students due to the level of their maturity. The process might be more difficult for students who are in the category of special needs. In traditional method of teaching which involved face to face interaction with pupil in the classroom or lecture hall, teachers and lecturers can give immediate feedback to the students. Face to face feedback has more positive impact on students, as it makes teaching and learning processes easier, richer, and more significant, and at the same time raising the motivation levels of the students. 2. Online teaching and learning process might lead to social isolation. It is very important for every students whether they are in schools or universities to have social interaction especially among their colleague. Social interaction is crucial for every pupil to build up their character and developed communication skills. It is very challenging for pupils to socialize through online education as student only face with the computer at all time. Though it is possible for students to socialize through computer among their friends but it is not the same with face to face social interaction. Social isolation coupled with a lack of communication skills can potentially lead to several mental health issues such as heightened stress, anxiety, and negative thoughts. 3 . Online teaching and learning process requires high level of self-motivation and disciplinary attitudes. Lack of self-motivation and indiscipline attitude among students can become a major obstacle to make online education a success. In traditional classrooms or lecture halls, there are numerous factors which can constantly push students towards their learning goals. Face to face communication with teachers or lecturers, peer to peer activities and strict schedules all work in unison to keep the students from falling off track during their studies. Online teaching and learning environment however provides less external factors which can push students to perform well in their study. In many situations, students being left to fend for themselves without anyone constantly urge them. Students whether they are in school level or university level need external factors to push them harder in their study. 4. Cheating prevention during online assessments is complicated. It is tough to prevent cheating process committed through online. Online education requires mutual trust between educators and their pupils. How can educators prevent cheating especially during students assessment process like examination, test, quiz, questions and answers session is hard to know. 5. Difficulties to present practical aspect of the subject. Depend on the technology used to conduct the online teaching and learning as well the courses taken, it can be very difficult process to 
exposed and explain to the students over the practical aspect of the course. 6. Online education is inaccessible to the computer illiterate population. Not everyone knows to use computer. Some of the educators are themselves also struggling to use computer and modern devices. To make online education a success, it will require all concern parties namely the educators and students to have skills in using computer or any modern devices to carry out the online education process smoothly and effectively. 7. Lack of accreditation \& quality assurance in online education. Though online education has increasingly become popular and important method of teaching and learning process in many countries, it's still having subject to challenges like the issue pertaining to accreditation and quality assurance. Certain university level courses still prefer by certain bodies to be carry out in the traditional ways in order to maintain and preserve it quality. There are certain bodies which are yet to accept the reality of the modern world in using online education as a method of teaching and learning. Lack of accredited and quality assurance can weaken the legitimacy of online education itself entirely.

Besides highlighting the problems or bad the sides of online education above, we also have been exposed with many ugly sides of online education in the country. There have been several reported news whereby students facing with huge obstacles to continue with their online lesson. Some of examples below are being reported from several local newspapers which can shared the real picture over the ugly sides of online education implementation in the country. In early June 2020, a university student from Sabah has gained public attention in the country for her backbreaking efforts to take her online examinations. Veveonah Mosibin posted a video to her YouTube channel showing viewers how she spent 24 hours on top of a tree in the jungle just to get the best internet connection for her chemistry and Malaysian studies exams on that day. She had initially built a mud hut with a bamboo floor and thatched roof on top of a hill specifically for this purpose but was crestfallen when she discovered that the structure had been destroyed by heavy rain the week before her exams. She quickly devised a new plan and climbed to the top of a tree armed with a mosquito net, her mobile phone, a power bank, food and water, and stationery to ace her tests. After her video went viral, many peoples in the country started to give their support to Vevenoah. Veveonah later uploaded a new video thanking people for their support. (Stephanie Lee, 2020 and Tan Mei Zi, 2020). Her effort to get online connection in order for her to continue with her study really a heartbreaking moment for everyone in the country. After her story came out, more similar stories started to emerge claiming that there are more students struggling to get internet excess just to continue with their online lesson. (Anthony Aga, 2020). Malaysia is not a third world country, yet facing with basic problem over internet connection. Many peoples started to ask questions pertaining to government efforts and commitment in providing basic facilities to the people. There is also issue raised from the public pertaining to safety concern of the pupil in the country to continue with the online education. Many started to ask whether the government has a comprehensive plan to ensure the smoothness and effectiveness of online education in the country. In late November 2020, it was reported that eight students in Sabah's interior district of Ranau who depended on a particular spot on a suspension bridge to gain internet access for an online class were badly injured when the bridge they were crossing collapsed. According to Deputy Chief Minister Datuk Joachim Gunsalam, the students from Sekolah Menengah Kebangsaan (SMK) Ulu Sugut had been on the bridge in Kampung Gusi at around 9pm when the wire mesh and wooden bridge collapsed. The bridge is old and there has been on and off repairs but it is rickety. The fall is said to be around 18 metres. One student, a 16 year old girl, broke bones in her thigh and shin while a male student suffered spinal injuries. The rest reportedly sustained light injuries. All eight of the students aged between 15 and 18 years' old are receiving treatment at the Ranau district hospital. The bridge is said to be one of the few spots in the village where the cellular signal needed for Internet access was intermittently available at night time. (Julia Chan, 2020 and Asyikin Asmin, 2020). When the quest to seek knowledge started to involve the risk of getting serious injury and even people life, we need to ask one simple question, is it worth to continue with online education? To answer such question, it worth for us to realize that, there is nothing wrong with the online method of teaching and learning process, the only problem we have would be in term of the providing safer environment, enough proper and adequate facilities along with adequate training to make online education a success. This would require strong political will and government commitment to ensure every concern parties able to carry out online education process smoothly and effectively. Without the present of strong political will and government commitment, it would certainly hamper in making online education process as part of our national education policy.

\subsection{THE WAY FORWARD}

The Malaysian government through Ministry of Education (MOE) and Ministry of Higher Education (MOHE) should draft a comprehensive plan to make online teaching and learning in our schools and universities as part of our education policy and to be fully and permanently implemented in the country as it would serve many benefits to everybody in the education sectors especially the students. Though the plan to utilised 
online teaching and learning has been developed in the country for the last many years and been implemented in some schools and universities, but it has not been implemented and utilised entirely. Only when we are facing with emergency moment like today with the spread of Covid-19 disease and the instruction over closure of schools and universities by the government everybody started to force themselves to fully make used such modern method of teaching and learning process.

Covid-19 is a contagious virus which can cause serious harm to people health and might also lead to death. Until today, millions of peoples have been reported to have been infected and over a million of peoples have died to its infection which being reported around the globe. The most vulnerable groups of peoples like the elders, individual which have weak immune system in their body and those who are suffering from chronic diseases are at high risk to get serious health effect from such virus. Due to the frightening nature of Covid19 , governments in all countries including in Malaysia has taken drastic measures to stop the spread of Covid-19. Among the drastic measure taken by Malaysian government includes the implementation of Movement Control Order (MCO) beginning 18 March which witnessed the closure of many business premises as well as schools and universities in the country.

Though schools and universities has been close for many months, the government has encourage all concern parties namely educators and students to make use of online teaching and learning process. Though some are not used and comfortable to online teaching and learning process and others might face some problem or difficulty to get internet excess or not having basic facilities to undergo online teaching and learning, it cannot become an excuse to abandon totally the idea over online teaching and learning process. Online education brings many advantages to everybody especially to the students themselves. Some of the advantages to online education include course material accessibility, flexible scheduling, more academic options, and the opportunity to build valuable high tech skills among the pupils. Time has change; technology will continue to develop in the future which can make online education more smooth and effective method of teaching and learning in schools and universities. The government should highlight the issue in making online teaching and learning as part of our national education policy. More money need to be allocated in this area of education so that everybody can have excess and fully utilized this modern mode of education. Our teachers, lecturers and students in schools and universities need to be given enough facilities and more training in order to make online teaching and learning permanent reality and not just to be used or utilized during emergency period of pandemic.

\subsection{AMPLIFYING THE NEED FOR MORE INVESTMENT IN EDUCATION TECHNOLOGY}

Through its implementation over several months in the year 2020, online learning and teaching have been shown as an important pedagogy that needs serious attention. Given that the pandemic was not a foreseeable circumstance, online learning and teaching have been an alternative to conventional teaching. Now, it is a method of teaching and learning that will stay. Chan (2020) discussed that the hybrid between conventional education and online education is a prospect that will happen in the education sector and it is up to people involved with the sector to structure an effective framework in executing it. The mechanism of online teaching is simple, user interface friendly and flexible. These criteria are exactly how education should work as these are how it will attract people to venture into the education sector. Razavi (2020) informed that a huge number of students in the United Kingdom are considering on starting their new term online and they have been happy with their online classes so far.

With more people anticipating and familiarizing themselves with online education and more online learning platforms are getting the recognition and being used in the classroom to facilitate teaching and learning, it is only natural that there is a need for more investment in education technology. The current technology that people are depending on to go through with their online learning classes are at a good state, however, investment in making education technology better will revolutionize online learning and teaching as a whole, and together it solidifies online education as an established discipline of knowledge. Various tech giants are spending billions of dollars on education technology as there is an acknowledgement that online education will be the future of for education. In China, the education technology market is soaring at an extremely high and it is continuously growing. Roof, Nair, Prinsloo, and Tse (2020) reported that Tencent has recently spent more than 3 billion on education technology in China. The investment is made with hopes that they can reform the online education market and create a more engaging online learning experience for students.

Moreover, more investment would mean in the creation of specific and catered approaches in education. BJYU, an Indian education tech company offers a personalized learning process through various ways such as multimedia presentation, live animations, video streaming, and mobile applications to its learners (Tan, 
2019). Such elaborate effort was made possible due to the pouring investment into the education technology market. With more investment in the online education sector, there would be more efforts in creating comprehensive online learning and teaching for students and teachers, respectively. The investment would not only result in advanced technologies such as Virtual Reality (VR) systems being used in the classroom, but it will also reform the local education structure. Dowson Tong, a senior executive vice-president of Tencent, discussed these visionary plans during Tencent's first MEET EdTech Innovation Summit, to which he stated:

"Tencent also unveiled a smart education plan to promote the construction of informatization infrastructure in education and help improve teachers' informatization competence. Under the plan, Tencent will work with management departments, institutions and partners to offer high-quality educational resources for 100 povertystricken counties, build 1,000 smart campuses with digital management and learning platforms, and cultivate 10,000 campus chief information officers (Shijia, 2019)".

Conclusively, online learning and teaching is something that will stay and with rigorous investment in education technology, the field will definitely be massive and it will surely open up the horizon of education.

\section{REFERENCE LIST}

ABC/Reuters. (January 29, 2008). Black death 'discriminated' between victims (ABC News in Science). Australian Broadcasting Corporation. http://www.abc.net.au/science/articles/2008/01/29/2149185.htm. Retrieved on December 10, 2020.

Alasdair Sandford. (April 3, 2020). Coronavirus: Half of humanity now on lockdown as 90 countries call for confinement. Euronews. https://www.euronews.com/2020/04/02/coronavirus-in-europe-spain-sdeath-toll-hits-10-000-after-record-950-new-deaths-in-24-hou. Retrieved on December 10, 2020.

Amir Yusof. (August 28, 2020). Malaysia's recovery movement control order extended to Dec 31, tourists still not allowed in: PM Muhyiddin. Channel News Asia (CNA).

https://www.channelnewsasia.com/news/asia/malaysia-recovery-movement-control-order-extendeddec-31-mco-13047724. Retrieved on December 10, 2020.

Anthony Aga. (June 27, 2020). Students head to jungle for internet coverage. Borneo Post. https://www.theborneopost.com/2020/06/27/students-head-to-jungle-for-internet-coverage/. Retrieved on December 11, 2020.

Asyikin Asmin. (November 26, 2020). Tiga pelajar cedera jatuh jambatan ketika dapatkan internet. Sinar Harian. https://www.sinarharian.com.my/article/112110/EDISI/Sabah-Sarawak/Tiga-pelajar-cederajatuh-jambatan-ketika-dapatkan-internet. Retrieved on December 11, 2020.

Cindi Loo. (June 7, 2020). CMCO ends June 9, Recovery MCO from June 10 to Aug 31 (Updated). The Sun Daily. https://www.thesundaily.my/local/cmco-ends-june-9-recovery-mco-from-june-10-to-aug-31updated-EM2538754. Retrieved on December 10, 2020.

Centers for Disease Control and Prevention (CDC). https://www.cdc.gov/coronavirus/2019ncov/cdcresponse/about-COVID-19.html. Retrieved on December 10, 2020.

Chan, H. (October 27, 2020). Covid-19 won't last forever, but online learning here to stay, former Hong Kong finance chief says in predicting 'new normal' for education. South China Morning Post. https://www.scmp.com/news/hong-kong/education/article/3107108/covid-19-wont-last-forever-onlinelearning-here-stay. Retrieved on December 12, 2020.

Coronavirus disease (COVID-19) advice for the public. World Health Organization (WHO). https://www.who.int/emergencies/diseases/novel-coronavirus-2019/advice-for-public. Retrieved on December 10, 2020.

Covid-19: Movement Control Order imposed with only essential sectors operating. March, 16 2020. New Straits Times. https://www.nst.com.my/news/nation/2020/03/575177/covid-19-movement-controlorder-imposed-only-essential-sectors-operating. Retrieved on December 10, 2020.

Dworak, A. (2020). United States University Enrollment Numbers During the COVID-19 Pandemic Recession 
. Perspectives on the New Normal: Post COVID19, 67.

Eleanor Busby. (October 16, 2020). Universities face mounting pressure to switch to online classes amid Covid-19. MSN News. https://www.msn.com/en-gb/news/uknews/universities-face-mountingpressure-to-switch-to-online-classes-amid-covid-19/ar-BB1a674v. Retrieved on December 11, 2020.

Farah Nurshahira Zulkifli and Md Yusoff Daud. (2017). Transformasi Pendidikan: Isu dan Cabaran Pendidikan Abad Ke - 21 Melalui Aplikasi Mssive Open Online Courses (MOOC) di Malaysia. Simposium Pendidikan diPeribadikan: Perspektif Risalah An-Nur (SPRiN2017).

Friga, P. N. (2020). Under Covid-19, University Budgets Like We've Never Seen Before. The Chronicles of Higher Education, 6-8.

Global HIV \& AIDS statistics - 2019 fact sheet. UNAIDS. https://www.unaids.org/en/resources/fact-sheet. Retrieved on December 10, 2020.

Hall, R. (2010). The work-study relationship: experiences of full-time univesity students undertaking part time employment. Journal of Education and Work, 440.

Health: De-coding the Black Death. BBC. October, 3 2001. http://news.bbc.co.uk/2/hi/health/1576875.stm.

Hye Jung Han. (March 27, 2020). As Schools Close Over Coronavirus, Protect Kids' Privacy in Online Learning. https://www.hrw.org/news/2020/03/27/schools-close-over-coronavirus-protect-kids-privacyonline-learning. Retrieved on December 10, 2020.

Ida Lim. (May 30, 2020). Reality for Malaysia's university students: Online learning challenges, stress, workload; possible solutions for fully digital future until Dec. Malay Mail. https://www.malaymail.com/news/malaysia/2020/05/30/reality-for-malaysias-university-studentsonline-learning-challenges-stress/1870717. Retrieved on December 10, 2020.

Jacqueline Howard. (2020). What is a pandemic?. Cable News Network (CNN). https://edition.cnn.com/2020/02/25/health/what-is-a-pandemic-explainer/index.html. Retrieved on December 10, 2020.

Julia Chan. (November 26, 2020). In Sabah, students fall from suspension bridge they climbed to get internet access. https://www.malaymail.com/news/malaysia/2020/11/26/in-sabah-students-fall-fromsuspension-bridge-they-climbed-to-get-internet/1926481. Retrieved on December 11, 2020.

Justin Ong. (July 16, 2020). Education Ministry: Over one in three students couldn't access online learning during MCO. https://www.malaymail.com/news/malaysia/2020/07/16/education-ministry-over-one-inthree-students-couldnt-access-online-learnin/1885005. Retrieved on December 10, 2020.

Kemp, N., \& Grieve, R. (2014). Face-to-face or face-to-screen? Undergraduates' opinions and test performance in classroom vs. online learning. Frontiers in Psychology.

Kenneth Tee. (March 25, 2020). PM: Covid-19 shutdown extended to April 14. Malay Mail. https://www.malaymail.com/news/malaysia/2020/03/25/pm-covid-19-shutdown-extended-to-april14/1850034. Retrieved on December 10, 2020.

Kentnor, H. (2015). Distance Education and the Evolution of Online Learning in the United States. Curriculum and Teaching Dialogue, 29-30.

Khairah N. Karim. (March 19, 2020). MCO guidelines: Students not allowed to leave hostels. New Straits Times. https://www.nst.com.my/news/nation/2020/03/576239/mco-guidelines-students-not-allowedleave-hostels. Retrieved on December 10, 2020.

Kohli, S. (October 15, 2015). Why you can get a free college education in Germany but not in California. The LA Times. https://www.latimes.com/local/education/community/la-me-edu-free-college-education-ingermany-but-not-in-california-20151029-htmlstory.html. Retrieved on December 12, 2020.

MCO extended until April 28 - PM Muhyiddin. (April 10, 2020). Bernama. https://www.bernama.com/en/general/news_covid-19.php?id=1830577. Retrieved on December 10, 2020.

MCO extended another two weeks to May 12 - Muhyiddin. (April 23, 2020). Bernama. https://www.bernama.com/en/general/news.php?id=1835248. Retrieved on December 10, 2020.

Ministry of Health (MOH), Malaysia. http://covid-19.moh.gov.my/. Retrieved on December 10, 2020. 
Ott, M. (November 18, 2020). Why for-profit college enrollment has increased during COVID-19. The Conversation. https://theconversation.com/why-for-profit-college-enrollment-has-increased-duringcovid-19-148619. Retrieved on December 12, 2020.

Permana, P., \& Permatawati, I. (2019). Using Quizizz as a Formative Assessment Tool. Advances in Social Science, Education and Humanities Research, 157.

Perintah Kawalan Pergerakan bersyarat akan dilaksana - Muhyiddin. (May 1, 2020). Bernama. https://www.bernama.com/bm/news.php?id=1837419. Retrieved on December 10, 2020.

Priya, R. (April 25, 2020). Survival strategies for businesses during COVID-19 lockdown. The Economic Times. https://economictimes.indiatimes.com/small-biz/hr-leadership/leadership/survival-strategiesfor-businesses-during-covid-19-lockdown/articleshow/75371157.cms. Retrieved on December 12, 2020.

Radzi Razak. (April 10, 2020). PM says schools to stay closed, home-based learning to be utilised during MCO. Malay Mail. https://www.malaymail.com/news/malaysia/2020/04/10/pm-says-schools-to-stayclosed-home-based-learning-to-be-utilised-during-mc/1855459. Retrieved on December 10, 2020.

Razavi, L. (May 27, 2020). 'Students like the flexibility': why online universities are here to stay. The Guardian: https://www.theguardian.com/education/2020/may/27/students-like-the-flexibility-whyonline-universities-are-here-to-stay. Retrieved on December 12, 2020.

Ritesh Presswala. (June 2, 2020). In Charts | COVID-19 impact on global trade, education and crime. https://www.msn.com/en-in/news/crime/in-charts-covid-19-impact-on-global-trade-education-andcrime/ar-BB14V6Hu. Retrieved on December 12, 2020.

Roof, K., Nair, D., Prinsloo, L. and Tse, C. (November 12, 2020). Tencent to invest in online education startup Udemy. Money Web. https://www.moneyweb.co.za/news-fast-news/tencent-to-invest-inonline-education-startup-udemy/. Retrieved on December 12, 2020.

Rogers, S. (October 17, 2020). Minecraft Education is Making School a Lot More Fun This Fall. Yahoo! News. https://news.yahoo.com/minecraft-education-making-school-lot210022895. html?guccounter=1\&guce_referrer=aHR0cHM6Ly93d3cuZ29vZ2xILmNvbS8\&guce_refer rer_sig=AQAAAGOxnlaF8HoqU_XzOfSCDuJbmk3FufoLikWsV2wJzfDPgFRZtYnTbblOUaWVKIwLU XVFIKBOzS6BfBMboEgTyV0ucs8O39IgWE. Retrieved on December 12, 2020.

Samuels, B. (November 18, 2011). Why All Public Higher Education Should Be Free. Huffington Post. https://www.huffpost.com/entry/why-all-public-higher-edu_b_1099437. Retrieved on December 12, 2020.

Sander Tamm. (December 21, 2020). Disadvantages of E-Learning. https://e-student.org/disadvantages-ofe-learning/\#online-instructors-tend-to-focus-on-theory-rather-than-practice. Retrieved on December 11, 2020.

Shiija, O. (December 4, 2019). Tencent launches new smart education solution. China Daily. https://www.chinadaily.com.cn/a/201912/04/WS5de77c66a310cf3e3557bfef.html. Retrieved on December 12, 2020.

Simon Burgess, Hans Henrik Sievertsen. (April 1, 2020). Schools, skills, and learning: The impact of COVID19 on education. https://voxeu.org/article/impact-covid-19-education. Retrieved on December 10, 2020.

Siti Hajar Halili, Shukri Sulaiman, and Mohd Razha Abd Rashid. (2011). Keberkesanan Proses Pembelajaran Menggunakan Teknologi Sidang Video (The Effectiveness of Learning Process Using Video Conferencing Technology). Jurnal Pendidikan Malaysia 36 (1).

Siti Hajar Taib, Mohd Azaharin Ismail, and Maimun Aqsha Lubis Abdin Lubis. (2019). Inovasi Kesepaduan dan Strategi Pengajaran dan Pembelajaran Di Era Revolusi 4.0. ASEAN Comparative Education Research Journal on Islam and Civilization (ACER-J) 38 Volume 3 (2).

Soo Wern Jun. (November 8, 2020). Education Ministry: All schools nationwide to close starting tomorrow as CMCO in most states starts. Malay Mail.

https://www.malaymail.com/news/malaysia/2020/11/08/education-ministry-all-schools-nationwide-toclose-starting-tomorrow-as-cmc/1920572. Retrieved on December 11, 2020.

Stephanie Lee. (June 16, 2020). Sabah student stays overnight in tree to get better Internet connection for 
online university exams. The Star. https://www.thestar.com.my/news/nation/2020/06/16/sabah-unistudent-stays-overnight-in-tree-to-get-better-internet-connection-for-online-exams. Retrieved on December 11, 2020.

Tan Mei Zi. (June 17, 2020). Sabah university student spends 24 hours on top of a tree for better internet connection for online exams (VIDEO). Malay Mail. https://www.malaymail.com/news/life/2020/06/17/sabah-university-student-spends-24-hours-on-topof-a-tree-for-better-intern/1876231. Retrieved on December 11, 2020.

Tan, Z.Y. (June 9, 2019). Edtech: Investing in education technology. The Edge Malaysia. https://www.theedgemarkets.com/article/edtech-investing-education-technology. Retrieved on December 12, 2020.

Tashny Sukumaran. (March 16, 2020). Coronavirus: Malaysia in partial lockdown from March 18 to limit outbreak. This Week in Asia. https://www.scmp.com/week-asia/healthenvironment/article/3075456/coronavirus-malaysias-prime-minister-muhyiddin-yassin. Retrieved on December 10, 2020.

The Johns Hopkins Coronavirus Resource Center (CRC). https://coronavirus.jhu.edu/about. Retrieved on December 10, 2020.

The Prime Minister's Special Message on COVID-19 - 16 March 2020. (March 16, 2020). Prime Minister's Office of Malaysia Official Website. https://www.pmo.gov.my/2020/03/perutusan-khas-yab-perdanamenteri-mengenai-covid-19-16-mac-2020/. Retrieved on December 10, 2020.

WHO chief finally declares global coronavirus outbreak a pandemic. (March 12, 2020). Free Malaysia Today. https://www.freemalaysiatoday.com/category/highlight/2020/03/12/who-chief-finally-declares-globalcoronavirus-outbreak-a-pandemic/. Retrieved on December 10, 2020.

Yaseen, M. (February 11, 2019). Education is a right, not a privilege. Daily Times. https://dailytimes.com.pk/353287/education-is-a-right-not-a-privilege/. Retrieved on December 12, 2020. 